\title{
Synthesis and structure of Four-coordinate copper(II) complexes stabilized by $\beta$ - ketiminato ligands and application in the reverse Atom-Transfer Radical Polymerization of styrene
}

\author{
Stefano Gulli, ${ }^{[a]}$ Jean-Claude Daran, ${ }^{[a]}$ and Rinaldo Poli*[a,b]
}

\author{
Keywords: Copper(II) / Functionalized $\beta$-ketiminato ligands / Controlled Radical Polymerization / ATRP / Polystyrene
}

\begin{abstract}
The reaction of $\mathrm{CuCl}_{2}$ with $\mathrm{R}_{2} \mathrm{NCH}_{2} \mathrm{CH}_{2} \mathrm{NHC}(\mathrm{Me})=\mathrm{CHCO}(\mathrm{Me})(\mathrm{R}$ $=\mathrm{Me}, \mathrm{HL}^{1}$; or $\left.\mathrm{Et}, \mathrm{HL}^{2}\right)$ in the presence of $\mathrm{Et}_{3} \mathrm{~N}$ leads to the formation of complexes $\mathrm{CuCl}\left(\mathrm{L}^{\mathrm{n}}\right)(\mathrm{n}=1, \mathbf{1} ; 2,2)$. While the solid state structure of compound $\mathbf{2}$ is mononuclear with a close to square planar arrangement of the $\mathrm{ClON}_{2}$ donor set, compound $\mathbf{1}$ adopts a dinuclear di- $\mu$-chlorido arrangement where two mononuclear units having essentially the same arrangement as in $\mathbf{2}$ establish loose axial $\mathrm{Cu} \cdots \mathrm{Cl}$ interactions, each one of them with the $\mathrm{Cl}$ atom of the other one. Compounds $\mathbf{1}$ and $\mathbf{2}$ have been tested as reversible
\end{abstract}

\begin{abstract}
trapping agents for the controlled radical polymerization of styrene under a reverse ATRP approach. Reversible $\mathrm{Cl}$ atom transfer leading to a controlled polymerization process is observed, although the controllability is negatively affected by slow radical trapping. A moderate effect on the polymerization rate, once all the radical initiator is consumed, was observed in the presence of excess pyridine (10 equiv per $\mathrm{Cu}$ ) and interpreted on the basis of the stabilization of the $\mathrm{Cu}^{\mathrm{I}}$ system.
\end{abstract}

[a] Mr. S. Gulli, Dr. J.-C. Daran, Prof. R. Poli

CNRS; LCC (Laboratoire de Chimie de Coordination) Université de Toulouse; UPS, INPT

205, route de Narbonne, F-31077 Toulouse, France Fax: (+) 33-561553003

E-mail: rinaldo.poli@ lcc-toulouse.fr

Homepage: http://www.lcc-

toulouse.fr/equipe g/pages/poli/index.html

[b] Prof. R. Poli

Institut Universitaire de France

103, bd Saint-Michel, 75005 Paris, France

Supporting information for this article is available on the WWW under http://www.eurjic.org/ or from the author.

\section{Introduction}

Copper coordination chemistry with multidentate ligands has recently experienced a revival after the discovery ${ }^{[1]}$ and intensive development ${ }^{[2-5]}$ of $\mathrm{Cu}$-mediated controlled radical polymerization. This polymerization strategy rests on the reversible trapping of the growing radical chain, which is accomplished by transfer of a halogen atom from a $\mathrm{Cu}^{\mathrm{II}}-\mathrm{X}$ compound, yielding the corresponding $\mathrm{Cu}^{\mathrm{I}}$ complex and the halogen-terminated radical chain. The technique is therefore named "atom transfer radical polymerization" (ATRP). The process can be started from stable $\mathrm{Cu}^{\mathrm{I}}$ complexes, usually made in situ from $\mathrm{CuX}(\mathrm{X}=\mathrm{Cl}$ or $\mathrm{Br})$ and a suitable multidentate ligand, plus a halogenated compound $\mathrm{R}_{0} \mathrm{X}$ as initiator, in the presence of the polymerizable monomer (socalled ATRP conditions). Alternatively, it can be started from a stable $\mathrm{Cu}^{\mathrm{II}}$ complex (also usually made in situ from $\mathrm{CuX}_{2}$ and the appropriate ligand) and a standard radical source, in the presence of the monomer (so-called reverse ATRP conditions).

A recent review, focused on the structural aspects of coppercatalyzed ATRP, shows that the complexes used for this purpose are inevitably made by mixing $\mathrm{CuX}$ and $\mathrm{CuX}_{2}$ with neutral supporting ligands, therefore always containing a halogen atom in the coordination sphere. ${ }^{[6]}$ Occasionally, the halide is displaced to yield cationic complexes, such as for instance $\left[\mathrm{Cu}(\text { bipy })_{2}\right]^{+[7]}$ or $\left[\mathrm{Cu}\left(\mathrm{Me}_{6} \mathrm{TREN}\right)\right]^{+},{ }^{[8]}$ but the introduction of the anionic functionality into the multidentate ligand itself does not seem to have so far attracted much attention. We wish to explore here the use of anionic multidentate ligands for copper coordination chemistry, starting with the tridentate " $\mathrm{XL}_{2}$ " type. This is the minimum denticity likely to provide stable complexes in both oxidation states, since the $\mathrm{Cu}^{\mathrm{II}} \mathrm{Cl}\left(\mathrm{XL}_{2}\right)$ coordination environment is well established, for instance in $\mathrm{Tp} * \mathrm{CuCl}\left(\mathrm{Tp}^{*}=\operatorname{tris}(3,5-\right.$ dimethylpyrazolyl)borate), ${ }^{[9]}$ and the putative 3 -coordinate $\mathrm{Cu}^{\mathrm{I}} \mathrm{XL}_{2}$ system resulting from the halogen atom transfer may be stabilized by dimerization or by monomer coordination, as for instance in $[\mathrm{Tp} * \mathrm{Cu}]_{2}$ or $\mathrm{Tp} * \mathrm{Cu}$ (olefin) complexes. ${ }^{[10,11]}$

One of the simplest ways to introduce an anionic functionality in a chelating ligand is though deprotonation of a $\beta$-diketone such as acetylacetone. Since $\mathrm{Cu}$ has greater affinity to $\mathrm{N}$ ligands, modification of acetylacetone by introduction of a diamine was envisaged, to yield amine-functionalized $\beta$-ketimines, a well known class of ligands that has already been used to generate $\mathrm{Cu}^{\mathrm{I}}$ derivatives. ${ }^{[12-15]}$ We report here the synthesis and structural characterization of new copper(II) complexes incorporating these ligands, as well as a preliminary exploration of their ability to control the radical polymerization of styrene under reverse ATRP conditions.

\section{Results and Discussion}

Condensation of acetylacetone with one equivalent of $\mathrm{R}_{2} \mathrm{NCH}_{2} \mathrm{CH}_{2} \mathrm{NH}_{2}\left(\mathrm{R}=\mathrm{Me}\right.$, Et) yielded ligands $\mathrm{HL}^{1}$ and $\mathrm{HL}^{2}$ as shown in Scheme 1. ${ }^{[16-19]}$ Both ligands have recently been used in coordination chemistry with both main group ${ }^{[17,19]}$ and transition metals. ${ }^{[12,15,20]}$ The reaction of these ligands with anhydrous $\mathrm{CuCl}_{2}$ in THF, in the presence of one equivalent of triethylamine, provides a high-yield entry into complexes $\mathrm{CuCl}\left(\mathrm{L}^{1}\right), \mathbf{1}$, and $\mathrm{CuCl}\left(\mathrm{L}^{2}\right), 2$.

Complex 2 has already been recently described. ${ }^{[12]}$ It was synthesized in unreported yields by direct interaction of $\mathrm{CuCl}_{2}$ and $\mathrm{HL}^{2}$ in acetone at $60-65^{\circ} \mathrm{C}$ without use of a base and it was only 
characterized by IR spectroscopy. Our method uses NEt3, allowing the elimination of the generated $\mathrm{HCl}$ as $\mathrm{Et}_{3} \mathrm{NHCl}$, which precipitates in THF and can be easily removed by filtration, while the reaction is complete in less than $2 \mathrm{~h}$ at room temperature. The two compounds show a sharp EPR spectrum in dichloromethane solution at room temperature (Figure 1a), with the expected 1:1:1:1 hyperfine splitting caused by the $\mathrm{I}=3 / 2 \mathrm{Cu}$ nucleus. The dimethylamino derivative 1 reveals also an additional and barely discernible superhyperfine splitting, which may be caused by coupling to one of the $\mathrm{N}$ atoms $\left({ }^{14} \mathrm{~N}\right.$ : $\left.\mathrm{I}=1\right)$. The $\mathrm{g}$ tensor is tetragonal, as revealed by the spectrum taken at $120 \mathrm{~K}$ (Figure $1 \mathrm{~b}$ ), with a large $\mathrm{a} \|$ and a non discernible $\mathrm{a} \perp$.

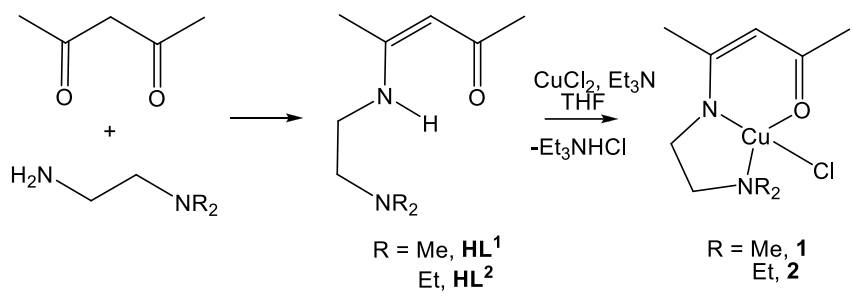

Scheme 1.
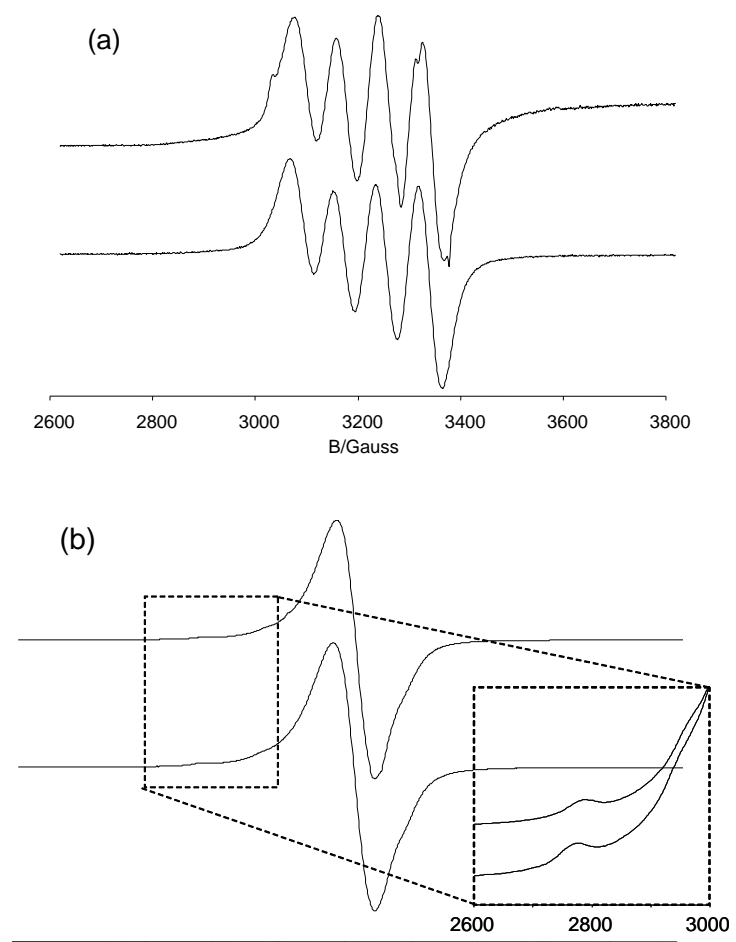

$\begin{array}{lllllllllll}2200 & 2400 & 2600 & 2800 & 3000 & 3200 & 3400 & 3600 & 3800 & 4000 & 4200\end{array}$

Figure 1. EPR spectra of compounds $\mathbf{1}$ (below) and $\mathbf{2}$ (above) in $\mathrm{CH}_{2} \mathrm{Cl}_{2}$ solution: (a) at room temperature; (b) at $120 \mathrm{~K}$.

Both complexes have been structurally characterized by X-ray diffraction. The structural chemistry of these molecules presents an interesting feature related to the nuclearity. Compound $\mathbf{2}$ is mononuclear and four-coordinate, with a close to square planar coordination geometry. When considering the plane of the electronically delocalized $\mathrm{Cu}(\beta$-ketiminato $)$ moiety, the donor $\mathrm{N}$ atom of the $\mathrm{Et}_{2} \mathrm{~N}$ moiety deviates only slightly (0.203(2) $\AA$ ) on one side of the plane, whereas the $\mathrm{Cl}$ atom deviates to a greater extent $(0.933(1) \AA)$ in the other direction. The trans $\mathrm{N} 1-\mathrm{Cu}-\mathrm{Cl}$ angle is significantly smaller than $180^{\circ}\left[163.62(4)^{\circ}\right]$, but the O-Cu-N2 angle is also rather small. The $\mathrm{Cl}-\mathrm{Cu}-\mathrm{O}$ plane makes a dihedral angle of $21.47(7)^{\circ}$ with the $\mathrm{N} 1-\mathrm{Cu}-\mathrm{N} 2$ plane. This distortion appears quite natural for this specific coordination environment. A search on the Cambridge Data Base for other 4-coordinate $\mathrm{Cu}$ complexes with a $\mathrm{ClON}_{2}$ donor set has revealed 42 mononuclear geometries, for which the average value of this specific dihedral angle is $11 \pm 7^{\circ}$.

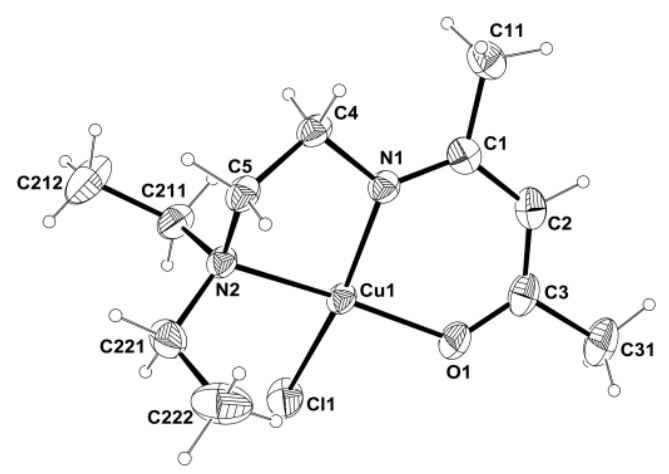

Figure 2. An ORTEP view of the molecule of compound 2, also showing the numbering scheme used. Thermal ellipsoids are drawn at the $50 \%$ probability level. Main geometrical parameters: $\mathrm{Cu}-\mathrm{Cl}, 2.2458(4)$; $\mathrm{Cu}-\mathrm{O}$, 1.9126(10); Cu-N1, 1.9404(12); Cu-N2, 2.0563(12) А; Cl-Cu-O, 91.92(4); Cl-Cu-N1, 163.62(4); Cl-Cu-N2, 93.46(4); O-Cu-N1, 92.92(5); O-Cu-N2, 166.32(5); N1-Cu-N2, 85.38(5) ${ }^{\circ}$.

Compound 1, on the other hand, is dinuclear, with bridging $\mathrm{Cl}$ atoms and 5-coordinate $\mathrm{Cu}$ centers. The bridging $\mathrm{Cu}_{2} \mathrm{Cl}_{2}$ moiety is in fact quite asymmetric, with very different $\mathrm{Cu}-\mathrm{Cl}$ distances. The shorter $\mathrm{Cu}-\mathrm{Cl}$ distance is only slightly lengthened relative to the $\mathrm{Cu}-\mathrm{Cl}$ distance in compound 2. Upon closer look, is it clear that the compound can be described as the dimerization of $\mathrm{CuCl}\left(\mathrm{L}^{1}\right)$ moieties that have a geometry very closely relate to that of the mononuclear compound 2 , through loose $\mathrm{Cu}-\mathrm{Cl}^{\mathrm{i}}$ and $\mathrm{Cu}^{\mathrm{i}}-\mathrm{Cl}$ interactions. Indeed, the coordination geometries around the $\mathrm{Cu}$ center in $\mathbf{1}$ and $\mathbf{2}$ are strikingly similar, including the deviation of the $\mathrm{Cl}-\mathrm{Cu}-\mathrm{N} 1$ angle from linearity and the dihedral angle between the $\mathrm{N} 1-\mathrm{Cu}-\mathrm{N} 2$ and $\mathrm{Cl}-\mathrm{Cu}-\mathrm{O}$ planes from coplanarity $\left(15.19(6)^{\circ}\right)$.

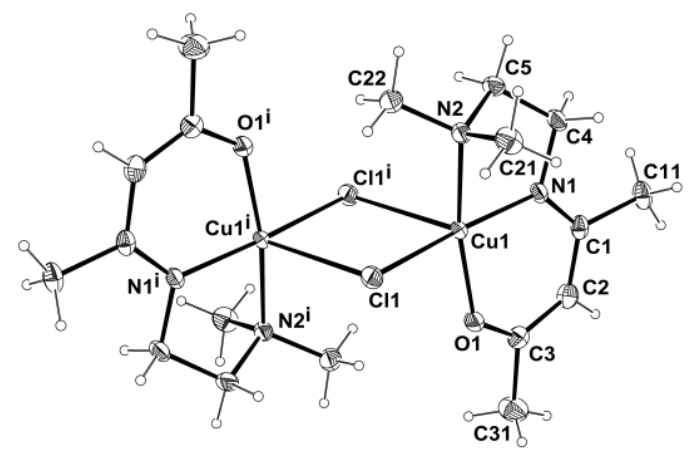

Figure 3. An ORTEP view of the molecule of compound 1, also showing the numbering scheme used. Thermal ellipsoids are drawn at the $50 \%$ probability level. Main geometrical parameters: $\mathrm{Cu}-\mathrm{Cl}, 2.3202(4)$; $\mathrm{Cu}-\mathrm{Cl}^{\mathrm{i}}=$ 2.8442(4); Cu-O, 1.917(1); Cu-N1, 1.9642(13); Cu-N2, 2.0610(13) A; Cl$\mathrm{Cu}-\mathrm{Cl}^{\mathrm{i}}=85.77(1) ; \mathrm{Cl}-\mathrm{Cu}-\mathrm{O}, 88.97(3) ; \mathrm{Cl}-\mathrm{Cu}-\mathrm{N} 1,170.47(4) ; \mathrm{Cl}-\mathrm{Cu}-\mathrm{N} 2$, 92.65(4); Cli-Cu-O, 97.56(4); Cli-Cu-N1, 103.40(4); Cli-Cu-N2, 95.25(4); O-Cu-N1, 92.34(5); O-Cu-N2, 167.17(5); N1-Cu-N2, 84.02(5) ${ }^{\circ}$. 
An interesting question therefore arises: why this nuclearity difference? The existence of the $\mathrm{Cu}-\mathrm{Cl}^{\mathrm{i}}$ interactions demonstrates the preference of a dinuclear structure, but their weakness suggests that their establishment may be discouraged by small perturbations. For compound $\mathbf{2}$, for which the shortest intermolecular contacts of the $\mathrm{Cl}$ atom are established with $\mathrm{C}-\mathrm{H}$ bonds of neighboring diethylaminoethyl moieties, the small perturbation is undoubtedly caused by the steric repulsion that the ethyl substituents would experience in a dinuclear structure. Indeed, the space filling model of compound 1, shown in Figure 4, indicates how one of the $\mathrm{NMe}_{2}$ methyl groups in one half of the molecule (right arrow) finds itselves in close proximity with the methyl group of the keto group in the other half og the molecule (left arrow), suggesting that a similar structure may not be sufficiently favoured with the bulkier $\mathrm{NEt}_{2}$-substituted ligand. It is then also interesting to re-examine the related mononuclear $\mathrm{Cu}$ structures containing a $\mathrm{ClON}_{2}$ ligand set already described in the literature, to identify the perturbation impeding dimerization in those cases.

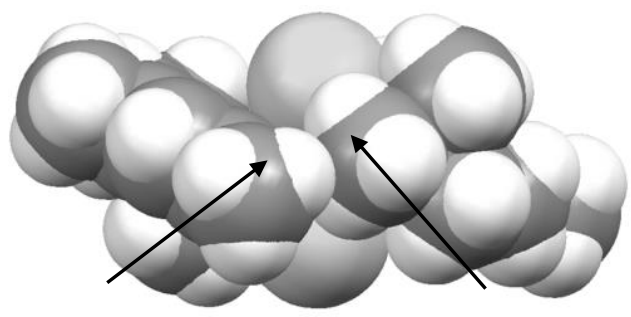

Figure 4. A space-filling view of the structure of compound $\mathbf{1}$

For a few compounds, the authors reported a 4-coordinate structure without realizing the presence of a loose axial interaction with an interstitial solvent molecule. This is the case for a few "methanol solvates", with $\mathrm{Cu}-\mathrm{O}$ distances to the axially bonded $\mathrm{MeOH}$ ligand as little as $2.27 \AA^{[21-23]}$ For another three compounds, the structure was described as mononuclear but it is in fact halide-bridged dinuclear, just like $\mathbf{1}$, with "loose" $\mathrm{Cu}-\mathrm{X}$ distances of $2.61^{[24]}$ and $2.84^{[25]} \AA(\mathrm{X}=\mathrm{Cl})$, or $3.09^{[26]}(\mathrm{X}=\mathrm{Br})$. In other cases, although axial donor atoms are far away for detection as bonding interactions (distance greater than the sum of van der Waals radii), the donor atom $(\mathrm{Cl}$ but sometimes also $\mathrm{O})$ is correctly positioned to provide some axial electron density to the $\mathrm{Cu}$ center in $2 \mathrm{D}$ or $3 \mathrm{D}$ packing arrangements. ${ }^{[27-32]}$ Interesting situations are presented by other structures that, like that of compound $\mathbf{2}$, are genuinely mononuclear, without significant additional contacts to the 4-coordinate $\mathrm{Cu}^{\mathrm{II}}$ center. A few of theses are polyaromatic compounds with delocalized planar ligands, which always display a $\pi$-stacking arrangement. ${ }^{[33-40]}$ This indicates that intermolecular $\pi$-staking interactions provide better stabilization to the crystal structure than the halide-bridge formation. In other cases, the dinuclear structure simply does not form because of the presence of a bulky group near the $\mathrm{Cu}$ center, either an $\mathrm{NEt}_{2}$ group like in compound $\mathbf{2},^{[41,42]}$ or another bulky group. ${ }^{[31,43,44]}$

The structure of compound $\mathbf{1}$ is identical to that of compound $\left[\mathrm{Cu}\left(\mathrm{L}^{1}\right)\left(\mathrm{O}_{2} \mathrm{CPh}\right)\right]_{2},{ }^{[15]}$ where the benzoate ligand occupies the same position as the $\mathrm{Cl}$ ligand in $\mathbf{1}$ by adopting a bridging monodentate $\left(\kappa^{1}: \mu\right)$ coordination mode, also with very different distances to the two $\mathrm{Cu}$ atoms (1.984(2) $\AA$ for the strong equatorial bond, $2.788 \AA$ for the loose axial bond). The $\mathrm{Cu}-\mathrm{N} 2$ bond (2.064(3) $\AA$ ) is essentially identical to that in $\mathbf{1}$, whereas the $\mathrm{Cu}-\mathrm{N} 1$ bond (1.914(3) $\AA$ ) is significantly shorter and the $\mathrm{Cu}-\mathrm{O} 1$ (1.944(3) $\AA$ ) is significantly longer. The structure of $\mathbf{2}$, on the other hand, may be directly compared with that of compound $\mathrm{CuCl}\left[\mathrm{Et}_{2} \mathrm{NCH}_{2} \mathrm{CH}_{2} \mathrm{~N}\right.$ $\mathrm{C}(\mathrm{Me}) \mathrm{CHC}(\mathrm{Ph}) \mathrm{O}$ ], the two compounds differing only by the nature of the substituent at the keto position ( $\mathrm{Ph} v s$. Me) ${ }^{[31]} \mathrm{In}$ the $\mathrm{Ph}$ substituted compound, the $\mathrm{Cu}-\mathrm{Cl}$ distance is significantly longer $(2.300 \AA)$, while the $\mathrm{Cu}-\mathrm{N} 1$ distance $(1.956 \AA)$ is marginally longer and the $\mathrm{Cu}-\mathrm{O}(2.107 \AA)$ and $\mathrm{Cu}-\mathrm{N} 2(1.992 \AA)$ distances are marginally shorter. The trans $\mathrm{Cl}-\mathrm{Cu}-\mathrm{N} 1$ angle $\left(164.8^{\circ}\right)$ is quite similar to that in $\mathbf{1}$.

Compounds $\mathbf{1}$ and $\mathbf{2}$ have been tested as controlling agents for the radical polymerization of styrene under reverse ATRP conditions. The first experiments carried out at $80^{\circ} \mathrm{C}$, with primary radicals generated from 2,2'-azobisisobutyronitrile (AIBN, $\mathrm{t}_{1 / 2}=\mathrm{ca}$. $70 \mathrm{~min}$ ), are shown in Figure 5a.
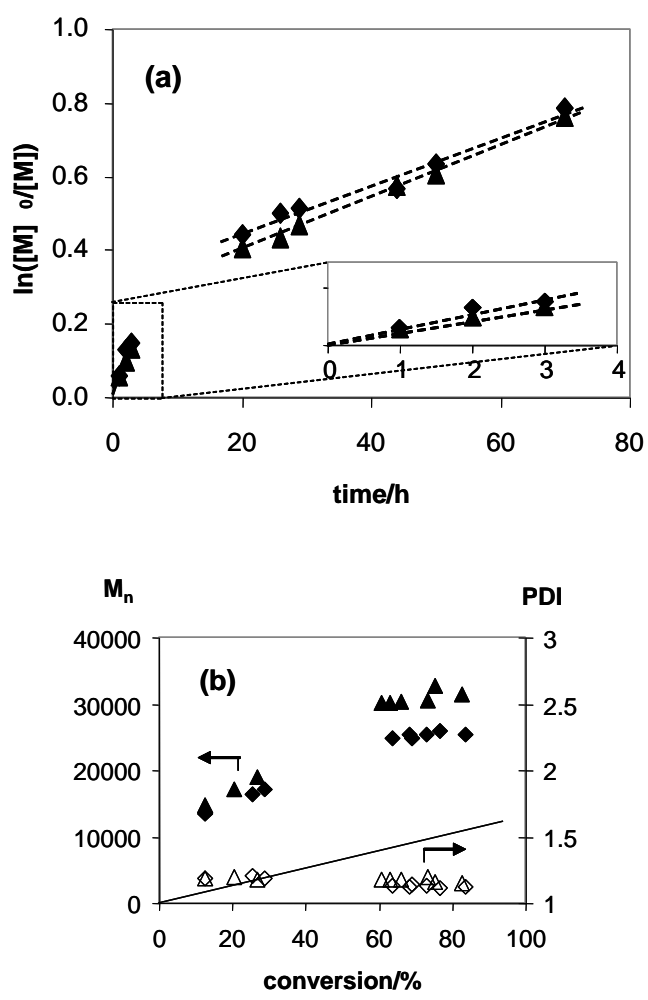

Figure 5. (a) First-order kinetic plot and (b) $\mathrm{M}_{\mathrm{n}}$ (filled symbols) and PDI (hollow symbols) $v s$. conversion for the radical polymerization of styrene in the presence of compounds 1 (triangles) or $\mathbf{2}$ (diamonds) The straight line in plot (b) indicates the theoretical molecular weight $\left(M_{R^{\circ}}+M_{M} \cdot\left(n_{M} / n_{C u}\right) \cdot p\right.$ $+\mathrm{M}_{\mathrm{Cl}}$; where $\mathrm{M}_{\mathrm{R}^{\circ}}, \mathrm{M}_{\mathrm{M}}$ and $\mathrm{M}_{\mathrm{Cl}}$ are the molar masses of primary radical, monomer and $\mathrm{Cl}$ atom, respectively, $\mathrm{p}$ is the degree of conversion, and $\left(\mathrm{n}_{\mathrm{M}} / \mathrm{n}_{\mathrm{Cu}}\right)$ is the molar ratio of monomer and $\left.\mathrm{Cu}\right)$. Conditions: $50 \%(\mathrm{v} / \mathrm{v})$ in toluene, $80^{\circ} \mathrm{C}$, [styrene]:[AIBN]:[Cu] = 200:0.8:1.

Several features of the two plots shown in Figure 5 deserve discussion. The first and most important one is that polymerization occurs and is sustained well beyond the time required to completely consume the radical initiator $(6-7 \mathrm{~h})$ in the presence of both compounds. Together with the continued increase of the number-average molecular weight and the low polydispersities of the resulting polymers at high conversion, this represents evidence that the radical chains are continuously generated from a dormant species and that the polymerization is controlled. Note that the first order kinetics plot indicates linearity in the high conversion region (after completely consuming the initiator), in agreement with a constant radical concentration in solution and with the occurrence of the ATRP mechanism. At low conversions (short times), on the other hand, the polymerization is faster. In addition, the molecular 
weights at low conversions are much greater than the expected values, but subsequently continue to grow at approximately the expected growth rate, while the polydispersity remains narrow throughout the polymerization process $(<1.2)$, see Figure $5 \mathrm{~b}$. This phenomenon can be ascribed to a slow trapping rate, generating chains of much higher molecular weight than expected during the initial phase of initiator decomposition. The relatively long initial phase of initiator decomposition (6-7 half-lives, namely 6-7 hours) entails the continuous generation of new radical chains throughout this period, but the molecular weight distribution does not appear to be too negatively affected by this initial phase or poor control.

The polymerization proceeds at approximately the same rate in the presence of compounds $\mathbf{1}$ and $\mathbf{2}$, both before and after depletion of the radical initiator (see Figure 5a), indicating that the activation/deactivation equilibrium is very similar for both copper compounds. In relation to the above described structural study of the two $\mathrm{Cu}^{\mathrm{II}}$ complexes, it is clear that the weak dichlorido-bridged interaction revealed for compound $\mathbf{1}$ does not play a major role in this process, as also indicated by the identical EPR spectroscopic properties of the two compounds in solution.

The putative $\mathrm{Cu}^{\mathrm{I}}$ catalyst generated by $\mathrm{Cl}$ atom transfer to the radical chain is a three-coordinated complex where the constraints of the ligand bite do not allow the metal center to adopt a preferred trigonal planar configuration. Although, as mentioned in the introduction, the complex may be stabilized by dimerization or by coordination of a monomer molecule, we wondered whether the addition of Lewis bases such as pyridine (py) or bipyridine (bipy) could affect the polymerization rate and controllability.

Because of the identical solution properties and polymerization results of compounds $\mathbf{1}$ and $\mathbf{2}$, additional experiments in the presence of py or bipy were only carried out with the ethylsubstituted complex 2 . The results (Figure 6) indicate a negligible effect on the reaction rate when using only 1 equiv of either additive. The difference between the three experiments may be considered to fall within the margins of the experimental error. The trends of $\mathrm{M}_{\mathrm{n}}$ and PDI as a function of conversion were also sensibly identical for the three experiments. When the $\mathrm{py} / \mathrm{Cu}$ ratio was increased to 10 , however, the polymerization was significantly retarded in the second period, after full consumption of the initiator, whereas the behaviour was once again identical before full consumption of the radical initiator. Therefore, it appears that the three-coordinate $\mathrm{Cu}^{\mathrm{I}}$ complex generated by $\mathrm{Cl}$ atom transfer, $\mathrm{Cu}\left(\mathrm{L}^{2}\right)$, can be stabilized by the Lewis base additive as shown in Scheme 2, the overall effect being a shift of the deactivation equilibrium toward the $\mathrm{Cu}^{\mathrm{I}}$ form. The absence of a notable effect on the rate during the first polymerization period is in agreement with the prediction that the Lewis additive action is restricted to the $\mathrm{Cu}^{\mathrm{I}}$ stabilization and does not affect the rate of $\mathrm{Cl}$ atom transfer from compound 2 to the growing radical chain (deactivation, $k_{\mathrm{d}}$ ).

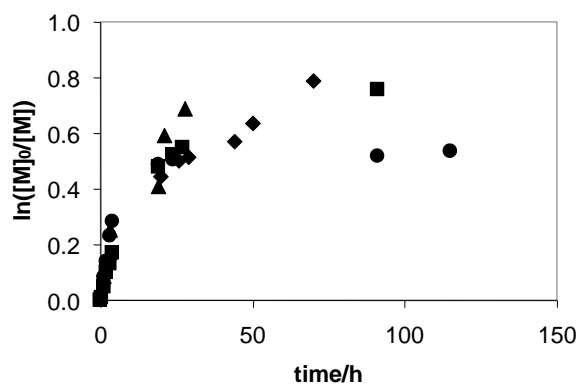

Figure 6. First-order kinetic plot for the radical polymerization of styrene in the presence of compound $\mathbf{2}$ alone (diamonds) or together with py (1 equiv, triangles; 10 equiv, spheres) or bipy (1 equiv, squares). Conditions are the same as in Figure 5.

An additional experiment was carried out in the presence of compound 2 and py ( 1 equiv) at lower temperature $\left(30^{\circ} \mathrm{C}\right)$. In this case, 2,2'-azobis(4-methoxy-2,4-dimethylvaleronitrile), V-70, was used as radical initiator $\left(\mathrm{t}_{1 / 2}=10 \mathrm{~h}\right)$. The results are compared with those obtained at $80^{\circ} \mathrm{C}$ in Figure 7. The polymerization rate is slower as expected. Once again, the process is sustained beyond the time needed to fully deplete the radical initiator (ca. $70 \mathrm{~h}$ for $\mathrm{V}$ 70 at $30^{\circ} \mathrm{C}$ ), with a visible breakpoint in the reaction rate, indicating reversible reactivation of the dormant chains by atom transfer to $\mathrm{Cu}^{\mathrm{I}}$. However, the controllability is not improved, as shown by the fact that the polymer $\mathrm{M}_{\mathrm{n}}$ is still large relative to the theory while the PDI is greater relative to the experiment at $80^{\circ} \mathrm{C}$. The reason for this result is that, while controllability in the second polymerization period is expected to increase, the lower temperature also causes a slower deactivation rate, negatively affecting the molecular weight distribution in the first polymerization period.
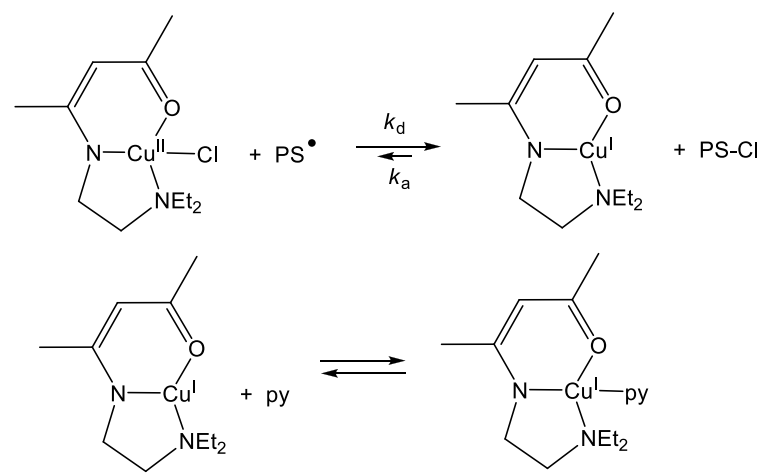

Scheme 2 .
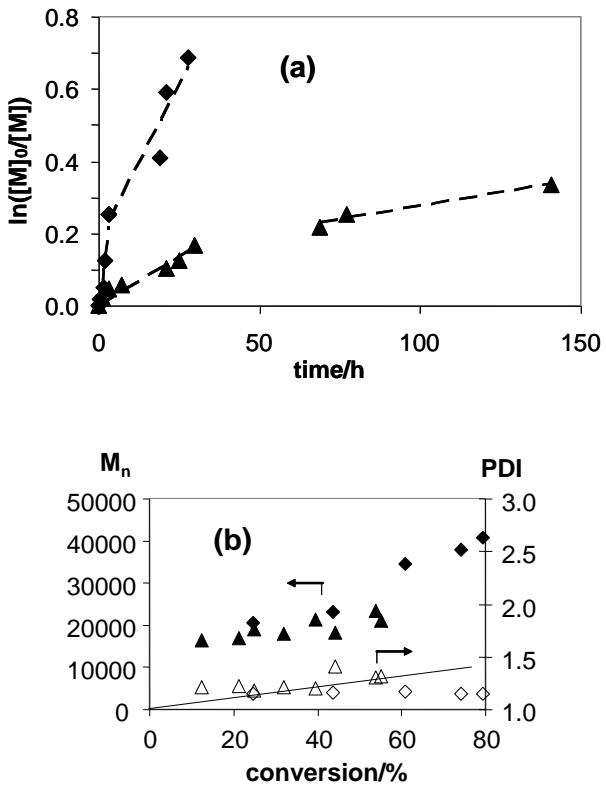

Figure 7. (a) First-order kinetic plot and (b) $M_{n}$ (filled symbols) and PDI (hollow symbols) vs. conversion for the radical polymerization of styrene in the presence of compound 2 and py (py/Cu $=1$ ) at $80^{\circ} \mathrm{C}$ (diamonds) and $30^{\circ} \mathrm{C}$ (triangles). The straight line in plot (b) indicates the theoretical molecular weight $\left(\mathrm{M}_{\mathrm{R}^{\circ}}+\mathrm{M}_{\mathrm{M}} \cdot\left(\mathrm{n}_{\mathrm{M}} / \mathrm{n}_{\mathrm{Cu}}\right) \cdot \mathrm{p}+\mathrm{M}_{\mathrm{Cl}}\right.$; where $\mathrm{M}_{\mathrm{R}^{\circ}}, \mathrm{M}_{\mathrm{M}}$ and $\mathrm{M}_{\mathrm{Cl}}$ are 
the molar masses of primary radical, monomer and $\mathrm{Cl}$ atom, respectively, $\mathrm{p}$ is the degree of conversion, and $\left(\mathrm{n}_{\mathrm{M}} / \mathrm{n}_{\mathrm{Cu}}\right)$ is the molar ratio of monomer and $\mathrm{Cu})$. Conditions for the experiment at $30^{\circ} \mathrm{C}$ : $50 \%(\mathrm{v} / \mathrm{v})$ in toluene, [styrene]:[V-70]:[Cu] = 200:0.8:1.

The slow radical trapping by complexes $\mathbf{1}$ and $\mathbf{2}$ may be directly related to the unsuitable geometry of the three-coordinate $\mathrm{Cu}^{\mathrm{I}}$ species that is formed by $\mathrm{Cl}$ atom transfer. As it has been previously pointed out, the best systems for rapid radical deactivation, which is crucial for good controllability, are those where the coordination geometry changes in a minimal way on going from $\mathrm{Ln}_{\mathrm{n}} / \mathrm{Cu}^{\mathrm{II}}-\mathrm{Cl}$ to $\mathrm{L}_{\mathrm{n}} / \mathrm{Cu}^{\mathrm{I}}$, while the electronic properties and the coordination geometry of the $\mathrm{L}_{\mathrm{n}}$ coordination sphere are most suitable to the $\mathrm{Cu}^{\mathrm{I}}$ species. In our case, the situation is quite the opposite, since the $\mathrm{L}^{1}$ and $\mathrm{L}^{2}$ ligands yield a suitable coordination environment for the $\mathrm{Cu}^{\mathrm{II}}$ system in combination with the $\mathrm{Cl}$ atom but are not at all adapted to the $\mathrm{Cu}^{\mathrm{I}}$ system.

\section{Conclusions}

We have prepared and characterized two neutral 4-coordinated $\mathrm{Cu}^{\mathrm{II}}$ monochloride complexes, disclosing new structural features related to weak intermolecular $\mathrm{Cu} \cdots \mathrm{Cl}$ bonding and discussing the criteria allowing this interaction to occur in these and other related complexes previously described in the literature. These complexes have been tested as reversible trapping agents for growing polystyrene radical chains under reverse ATRP conditions. While the systems are negatively affected by a slow trapping rate, the principle of reversible atom transfer leading to a controlled radical polymerization has been demonstrated. The trapping rate is expected to be accelerated by using other tridentate " $\mathrm{XL}_{2}$ " ligands with greater bites, thus adapting to a trigonal planar coordination for $\mathrm{Cu}^{\mathrm{I}}$, or perhaps even better by moving to tetradentate " $\mathrm{XL}_{3}$ " ligand that would stabilize $\mathrm{Cu}^{\mathrm{I}}$ in a tetrahedral environment. Research in our laboratory is now oriented along these directions.

\section{Experimental Section}

General: All solvents used in the reactions were distilled under argon. The NMR spectra were recorded on Bruker ARX 250 and AV300 instruments. Chemical shifts are expressed in ppm downfield from $\mathrm{Me}_{4} \mathrm{Si}$. Coupling constants are given in Hertz. The EPR spectra were measured on a Elexsys E500 BRUKER spectrometer (X-band) equipped with both a frequencemeter and gauss-meter. Acetylacetone, $\mathrm{N}, \mathrm{N}$-dimethylethylenediamine, $\mathrm{N}, \mathrm{N}$ diethylethylenediamine and $\mathrm{CuCl}_{2}$ were purchased from Sigma-Aldrich and used as received. Styrene (Sigma-Aldrich) was dehydrated by passing through a neutral alumina column and then stirred on $\mathrm{CaH}_{2}$ for 1 day, followed by distillation under argon.

\section{Synthesis of $\mathrm{Me}_{2} \mathrm{NCH}_{2} \mathrm{CH}_{2} \mathrm{NHC}(\mathrm{Me})=\mathrm{CHC}(\mathrm{Me})=\mathrm{O}, \mathrm{HL}^{1}$}

In a $500 \mathrm{ml}$ round-bottomed flask equipped with a condenser, $29.3 \mathrm{~g}(0.29$ mol) of acetyl acetone and $26 \mathrm{~g}(0.29 \mathrm{~mol})$ of N,N-dimethylethylenediamine in $250 \mathrm{ml}$ of benzene were refluxed for $48 \mathrm{~h}$ to yield an intense yellow solution. The conversion was monitored through measurement of the water removed from the reaction through a Dear-Stark apparatus. The reaction starts immediately, as suggested by the color change but two days of reflux were necessary to complete it. The solvent was then removed to yield an intense yellow-colored liquid. Distillation at $115^{\circ} \mathrm{C}$ yielded the product as a yellow oil. Yield: $47.1 \mathrm{~g}(95.5 \%) .{ }^{1} \mathrm{H}-$ $\mathrm{NMR}\left(\mathrm{C}_{6} \mathrm{D}_{6}, 250 \mathrm{MHz}\right): \delta 11.1$ (s(br), 1H, $\left.\mathrm{NH}\right), 4.98 \quad(\mathrm{~s}, 1 \mathrm{H}$, $\left.\mathrm{CH}_{3} \mathrm{CCHCCH}_{3}\right), 2.93$ (q, 2H, J = 6.2 Hz, $\left.\mathrm{NHCH}_{2} \mathrm{CH}_{2}\right), 2.15$ (t, $2 \mathrm{H}, \mathrm{J}=6.5$ $\mathrm{Hz}, \mathrm{NHCH}_{2} \mathrm{CH}_{2}$ ), 2.08 (s, 3H, $\mathrm{CH}_{3} \mathrm{CO}$ ), 2.06 (s, 6H, N( $\left.\left.\mathrm{CH}_{3}\right)_{2}\right), 1.63$ (s, 3H, $\left.\mathrm{CH}_{3} \mathrm{CN}\right) .{ }^{13} \mathrm{C}-\mathrm{NMR}\left(\mathrm{C}_{6} \mathrm{D}_{6}, 62.90 \mathrm{MHz}\right): \delta 193.6,161.5,95.0,58.9,45.2$, 40.9, 28.7, 18.4 .

\section{Synthesis of $\mathrm{Et}_{2} \mathrm{NCH}_{2} \mathrm{CH}_{2} \mathrm{NHC}(\mathrm{Me})=\mathrm{CHC}(\mathrm{Me})=\mathrm{O}, \mathrm{HL}^{2}$}

In a $500 \mathrm{ml}$ round-bottomed flask equipped with a condenser, $29.3 \mathrm{~g}(0.29$ $\mathrm{mol})$ of acetylacetone and $34 \mathrm{~g}(0.29 \mathrm{~mol})$ of $\mathrm{N}, \mathrm{N}$-diethylethylenediamine in $250 \mathrm{ml}$ of benzene were refluxed for $48 \mathrm{~h}$ to yield an intense yellow solution. The conversion was monitored through measurement of the water removed from the reaction through a Dear-Stark apparatus. The reaction starts immediately, as suggested by the color change but two days of reflux were necessary to complete it. The solvent was then removed to yield an intense yellow-colored liquid. Distillation at $145^{\circ} \mathrm{C}$ yielded the product as a yellow oil. Yield: $49.7 \mathrm{~g}(87.6 \%) .{ }^{1} \mathrm{H}-\mathrm{NMR}\left(\mathrm{C}_{6} \mathrm{D}_{6}, 300 \mathrm{MHz}\right): \delta 11.1$ (s, $6 \mathrm{H}), 4.98$ (s, 1H, $\left.\mathrm{CH}_{3} \mathrm{CCHCCH}_{3}\right), 2.93$ (q, 2H, J = 6.2 Hz, $\mathrm{NHCH}_{2} \mathrm{CH}_{2}$ ), 2.37 (q, 4H, J = 7.2 Hz, N( $\left.\left.\mathrm{CH}_{2} \mathrm{CH}_{3}\right)_{2}\right), 2.34\left(\mathrm{t}, 2 \mathrm{H}, \mathrm{J}=6.6 \mathrm{~Hz}, \mathrm{NHCH}_{2} \mathrm{CH}_{2}\right.$ ), $2.08\left(\mathrm{~s}, 3 \mathrm{H}, \mathrm{CH}_{3} \mathrm{CO}\right), 1.64\left(\mathrm{~s}, 3 \mathrm{H}, \mathrm{CH}_{3} \mathrm{CN}\right), 0.98(\mathrm{t}, 6 \mathrm{H}, \mathrm{J}=7 \mathrm{~Hz}$, $\left.\mathrm{N}\left(\mathrm{CH}_{2} \mathrm{CH}_{3}\right)_{2}\right) .{ }^{13} \mathrm{C}\left\{{ }^{1} \mathrm{H}\right\}-\mathrm{NMR}\left(\mathrm{C}_{6} \mathrm{D}_{6}, 75.47 \mathrm{MHz}\right): \delta 193.5,161.4,95.0$, 52.9, 47.3, 41.5, 28.7, 18.5, 12.1 .

\section{Synthesis of compound $\mathrm{CuCl}\left(\mathrm{L}^{1}\right), 1$}

To a solution of $\mathrm{CuCl}_{2}(5 \mathrm{~g}, 0.038 \mathrm{~mol})$ in $10 \mathrm{ml}$ of THF, a solution of $\mathrm{HL}^{1}$ (7.5 g, $0.038 \mathrm{~mol}$ in $10 \mathrm{ml}$ of THF) was added, followed by stirring for $1 \mathrm{~h}$ at room temperature. The solution became dark green. Then, $5.5 \mathrm{ml}(0.04$ mol) of $\mathrm{Et}_{3} \mathrm{~N}$ was added, followed by stirring for another $1 \mathrm{~h}$, resulting in the formation of a white precipitate $\left(\mathrm{Et}_{3} \mathrm{NH}^{+} \mathrm{Cl}^{-}\right)$, which was then removed by filtration. The solvent was partially removed under reduced pressure to about $5 \mathrm{ml}$ and slow diffusion of hexane gave black crystals suitable for analysis and for the X-ray diffraction analysis. Yield: $9.1 \mathrm{~g}(98.1 \%)$. Anal. Calcd. for $\mathrm{C}_{9} \mathrm{H}_{17} \mathrm{ClCuN}_{2} \mathrm{O}$ : C, 40.30; H, 6.39; N, $10.44 \%$. Found: C, 39.6; $\mathrm{H}, 6.8 ; \mathrm{N}, 10.3 \%$. EPR $\left(\mathrm{CH}_{2} \mathrm{CH}_{2}, \mathrm{rt}\right): \mathrm{g}=2.097 ; \mathrm{a}_{\mathrm{Cu}}=83.4$ G. EPR $\left(\mathrm{CH}_{2} \mathrm{CH}_{2}, 120 \mathrm{~K}\right): \mathrm{g}_{\|}=2.20(\mathrm{a} \|=\mathrm{ca} \quad .190 \mathrm{G}), \mathrm{g}_{\perp}=2.08$.

Synthesis of compound $\mathrm{CuCl}\left(\mathrm{L}^{2}\right), 2$

To a solution of $\mathrm{CuCl}_{2}(5 \mathrm{~g}, 0.038 \mathrm{~mol})$ in $10 \mathrm{ml}$ of THF, a solution of $\mathrm{HL}^{2}$ ( $6.5 \mathrm{~g}, 0.038 \mathrm{~mol}$ in $10 \mathrm{ml}$ of THF) was added, followed by stirring for $1 \mathrm{~h}$ at room temperature. The solution became dark green. Then, $5.5 \mathrm{ml}(0.04$ mol) of $\mathrm{Et}_{3} \mathrm{~N}$ was added, followed by stirring for another $1 \mathrm{~h}$, resulting in the formation of a white precipitate $\left(\mathrm{Et}_{3} \mathrm{NH}^{+} \mathrm{Cl}^{-}\right)$, which was removed by filtration. The solvent was partially removed under reduced pressure to about $5 \mathrm{ml}$ and slow diffusion of hexane gave black crystals suitable for analysis. Yield: $4.8 \mathrm{~g}(57.9 \%)$. Anal. Calcd. for $\mathrm{C}_{11} \mathrm{H}_{21} \mathrm{ClCuN}_{2} \mathrm{O}: \mathrm{C}, 44.59$; H, 7.14; N, $9.45 \%$. Found: C, 44.0; H, 7.7; N, $9.4 \%$. EPR $\left(\mathrm{CH}_{2} \mathrm{CH}_{2}, \mathrm{rt}\right): \mathrm{g}$ $=2.098 ; \mathrm{a}_{\mathrm{Cu}}=81.4 \mathrm{G} . \mathrm{EPR}\left(\mathrm{CH}_{2} \mathrm{CH}_{2}, 120 \mathrm{~K}\right): \mathrm{g} \|=2.20(\mathrm{a} \|=$ ca. $180 \mathrm{G})$, $\mathrm{g} \perp=2.09$.

\section{Standard procedure for the polymerization experiments}

The polymerizations were conducted in pre-dried Schlenk flasks. The solids (complexes, initiators and bipyridine) and a stirring bar were added, and then the flask was sealed with a glass septum. Oxygen was removed from the flask by applying vacuum and backfilling with argon (three cycles). The monomer and the solvents (pyridine, toluene and dodecane) were added via syringe. The solution was degassed by three freeze-pump-thaw cycles. A first sample was removed as reference and the flask immersed in an oil bath held by thermostat at the desired temperature. At timed intervals, samples were removed from the flask by syringe and diluted into THF. Every sample was filtered through neutral alumina to remove the catalyst. A small amount of this THF solution was used to determine the monomer conversion by gas chromatography (GS) with dodecane as an internal standard. From the remaining sample, the polymer product was precipitated by adding into excess $\mathrm{MeOH}$. The precipitate was collected and analyzed by GPC-SEC.

\section{X-ray crystallography}

A single crystal of each compound was mounted under inert perfluoropolyether on the tip of a glass fibre and cooled in the cryostream of either an Oxford-Diffraction XCALIBUR CCD diffractometer for $\mathbf{1}$ or an OxfordDiffraction GEMINI CCD diffractometer for 2. Data were collected using the monochromatic $\mathrm{MoK} \alpha$ radiation $(\lambda=0.71073)$. The structures were solved by direct methods (SIR97) ${ }^{[45]}$ and refined by least-squares procedures on $F^{2}$ using SHELXL-97. ${ }^{[46]}$ All $\mathrm{H}$ atoms attached to carbon 
were introduced in calculation in idealised positions and treated as riding models. The drawing of the molecules was realised with the help of ORTEP32. ${ }^{[4]}$ The crystal data and structure refinement parameters for both compounds are listed in Table 1.

Crystallographic data (excluding structure factors) have been deposited with the Cambridge Crystallographic Data Centre as supplementary publication no. CCDC 800731 \& 800732. Copies of the data can be obtained free of charge on application to the Director, CCDC, 12 Union Road, Cambridge CB2 1EZ, UK (fax: (+44) 1223-336-033; e-mail: deposit@ccdc.cam.ac.uk).

Table 1. Crystal data for compounds $\mathbf{1}$ and $\mathbf{2}$.

\begin{tabular}{|c|c|c|}
\hline Compound & 1 & 2 \\
\hline Empirical formula & $\mathrm{C}_{9} \mathrm{H}_{17} \mathrm{ClCuN}_{2} \mathrm{O}$ & $\mathrm{C}_{11} \mathrm{H}_{21} \mathrm{ClCuN}_{2} \mathrm{O}$ \\
\hline Formula weight & 268.24 & 296.30 \\
\hline Temperature, $\mathrm{K}$ & $180(2)$ & $180(2)$ \\
\hline Wavelength, $\AA$ & 0.71073 & 0.71073 \\
\hline Crystal system & Monoclinic & Monoclinic \\
\hline Space group & $\mathrm{P} 22_{1} / \mathrm{n}$ & $\mathrm{P} 2{ }_{1} / \mathrm{n}$ \\
\hline $\mathrm{a}, \AA$ & $10.2397(4)$ & $10.2616(3)$ \\
\hline $\mathrm{b}, \AA$ & $9.6133(4)$ & $9.7014(3)$ \\
\hline $\mathrm{c}, \AA$ & $12.3296(5)$ & $14.1431(4)$ \\
\hline$\alpha,{ }^{\circ}$ & $110.201(4)$ & $103.053(3)$ \\
\hline Volume, $\AA^{3}$ & $1139.03(8)$ & $1371.59(7)$ \\
\hline $\mathrm{Z}$ & 4 & 4 \\
\hline $\mathrm{D}$ (calcd), $\mathrm{Mg} / \mathrm{m}^{3}$ & 1.564 & 1.435 \\
\hline Abs. coeff., $\mathrm{mm}^{-1}$ & 2.122 & 1.770 \\
\hline $\mathrm{F}(000)$ & 556 & 620 \\
\hline Crystal size, $\mathrm{mm}^{3}$ & $0.12 \times 0.11 \times 0.07$ & $0.44 \times 0.34 \times 0.31$ \\
\hline Theta range, ${ }^{\circ}$ & 2.75 to $28.32^{\circ}$. & 3.48 to 29.12 . \\
\hline Reflts collected & 12338 & 15349 \\
\hline Unique reflts [R(int)] & $2646(0.0266)$ & $3263(0.0228)$ \\
\hline Completeness, $\%$, & 93.3 & 94.2 \\
\hline Abs. correction & Multi-scan & Multi-scan \\
\hline Max. / min. transm. & $\begin{array}{l}1.00000 \\
0.74280\end{array}$ & $1.00000,0.86185$ \\
\hline Refinement method & $\mathrm{F}^{2}$ & $\mathrm{~F}^{2}$ \\
\hline Data / restr. / param. & $2416 / 0 / 131$ & $3204 / 0 / 149$ \\
\hline Goodness-of-fit on $\mathrm{F}^{2}$ & 1.101 & 1.103 \\
\hline $\mathrm{R}, \mathrm{wR} 2[\mathrm{I}>2 \sigma(\mathrm{I})]$ & $0.0224,0.0601$ & $0.0217,0.0607$ \\
\hline R, wR2 (all data) & $0.0264,0.0616$ & $0.0289,0.0619$ \\
\hline Resid. density, e. $\AA^{-3}$ & 0.287 and -0.611 & 0.415 and -0.269 \\
\hline
\end{tabular}

Supporting Information: Tables of conversions, molecular weights and polydispersity index for the all polymerization experiments (2 pages).

\section{Acknowledgments}

We are grateful to the Agence National de la Recherche (Programme ANR Blanc "OMRP", 2010-13), the Centre National de la Recherche Scientifique (CNRS) and the Institut Universitaire de France (IUF) for support of this work and to the Politecnico, Milan, Italy for an Erasmus exchange fellowhip to SG. We also thank Dr. Zhigang Xue and Mr Andrés F. Cardozo for technical assistance.

[1] J.-S. Wang and K. Matyjaszewski, J. Am. Chem. Soc. 1995, 117, 5614-5615.

[2] K. Matyjaszewski and J. H. Xia, Chem. Rev. 2001, 101, 2921-2990.

[3] M. Kamigaito, T. Ando and M. Sawamoto, Chem. Rev. 2001, 101, 3689-3745.

[4] M. Ouchi, T. Terashima and M. Sawamoto, Chem. Rev. 2009, 109, 4963-5050.
[5] F. Di Lena and K. Matyjaszewski, Prog. Polym. Sci. 2010, 35, 9591021.

[6] T. Pintauer and K. Matyjaszewski, Coord. Chem. Rev. 2005, 249, 1155-1184.

[7] M. Munakata, S. Kitagawa, A. Asahara and H. Masuda, Bull. Chem. Soc. Jpn. 1987, 60, 1927-1929.

[8] M. Becker, F. W. Heinemann and S. Schindler, Chem. Eur. J. 1999, $5,3124-3129$

[9] N. Kitajima, K. Fujisawa and Y. Morooka, J. Am. Chem. Soc. 1990, $112,3210-3212$.

[10] C. Mealli, C. S. Arcus, J. L. Wilkinson, T. J. Marks and J. A. Ibers, J. Am. Chem. Soc. 1976, 98, 711-718.

[11] J. S. Thompson, R. L. Harlow and J. F. Whitney, J. Am. Chem. Soc. $1983,105,3522-3527$.

[12] Q. Zhao, W.-L. Cao, Z.-Y. Yang and J.-C. Zhang, Beijing Huagong Daxue Xuebao, Ziran Kexueban 2005, 32, 68-71.

[13] S. H. Hsu, C. Y. Li, Y. W. Chiu, M. C. Chiu, Y. L. Lien, P. C. Kuo, H. M. Lee, J. H. Huang and C. P. Cheng, J. Organomet. Chem. 2007, 692, 5421-5428.

[14] A. F. Lugo and A. F. Richards, Inorg. Chim. Acta 2010, 363, 2104 2112 .

[15] X. Zhang, H. Bian, W. Gu, F. Huang, S. Yan and H. Liang, Nankai Daxue Xuebao, Ziran Kexueban 2009, 42, 59-63.

[16] M. Becht, T. Gerfin and K. H. Dahmen, Helv. Chim. Acta 1994, 77, 1288-1298.

[17] H. Y. Tang, H. Y. Chen, J. H. Huang and C. C. Lin, Macromolecules $2007,40,8855-8860$

[18] C. Biswas, M. G. B. Drew and A. Ghosh, Inorg. Chem. 2008, 47, 4513-4519.

[19] A. F. Lugo and A. F. Richards, Eur. J. Inorg. Chem. 2010, 20252035 .

[20] L. A. Lesikar, A. F. Gushwa and A. F. Richards, J. Organomet. Chem. 2008, 693, 3245-3255.

[21] Y. M. Chumakov, M. D. Mazus, V. N. Biyushkin, N. I. Belichuk and T. I. Malinovskii, Izv. Akad. Nauk Mold. SSR, Ser. Fiz.-Tekh. Mat. Nauk 1979, 83-86.

[22] V. K. Kravtsov, V. N. Biyushkin, L. A. Nezhelskaya and T. I. Malinovskii, Koord. Khim. 1993, 19, 235-239.

[23] M. E. Bluhm, M. Ciesielski, H. Görls, O. Walter and M. Döring, Inorg. Chem. 2003, 42, 8878-8885.

[24] E. Gyepes, E. Kuchar and A. Jurikova, Acta Fac. Rerum Nat. Univ. Comenianae, Chim. 1981, 29, 69-80.

[25] J. M. Latour, S. S. Tandon, G. A. Leonard and D. C. Povey, Acta Crystallogr., Sect. C: Cryst. Struct. Commun. 1989, 45, 598-600.

[26] F. Hueso-Urena, M. N. Moreno-Carretero, A. L. Penas-Chamorro, J. M. Amigo, V. Esteve and T. Debaerdemaeker, Polyhedron 1999, 18 , 3629-3636.

[27] C. T. Zeyrek, A. Elmali and Y. Elerman, Z. Naturforsch. Sect. B 2006, 61, 237-242.

[28] J. C. Ma, J. Yang and J. F. Ma, Acta Crystallographica Section EStructure Reports Online 2007, 63, M2431-U1649.

[29] X. Y. Ma, X. D. Dong, Y. P. Li and Z. G. Zhang, Acta Crystallographica Section E-Structure Reports Online 2007, 63, M1729-U1327.

[30] A. M. Prokhorov, P. A. Slepukhin and D. N. Kozhevnikov, J. Organomet. Chem. 2008, 693, 1886-1894.

[31] B. Sarkar, G. Bocelli, A. Cantoni and A. Ghosh, Journal of Coordination Chemistry 2008, 61, 3693-3702.

[32] N. A. I. Hisham, H. M. Ali and S. W. Ng, Acta Crystallographica Section E-Structure Reports Online 2009, 65, M870-U453.

[33] K. D. Onuska, N. J. Taylor and J. Carsky, J. Chem. Crystall. 1996, 26, 841-846. 
[34] U. Sandbhor, S. Padhye, D. Billington, D. Rathbone, S. Franzblau, C. E. Anson and A. K. Powell, J. Inorg. Biochem. 2002, 90, 127-136.

[35] R. Kannappan, S. Tanase, I. Mutikainen, U. Turpeinen and J. Reedijk, Inorg. Chim. Acta 2005, 358, 383-388.

[36] R. Karmakar, C. R. Choudhury, A. S. Batsanov, S. R. Batten and S. Mitra, Struct. Chem. 2005, 16, 535-539.

[37] S. Das, S. A. Maloor and S. Pal, Crystal Growth \& Design 2006, 6, 2103-2108

[38] P. U. Maheswari, S. Roy, H. Den Dulk, S. Barends, G. Van Wezel, B. Kozlevcar, P. Gamez and J. Reedijk, J. Am. Chem. Soc. 2006, 128, 710-711.

[39] P. Barbazan, R. Carballo and E. M. Vazquez-Lopez, Crystengcomm 2007, 9, 668-675.

[40] A. Ray, G. Pilet, C. J. Gomez-Garcia and S. Mitra, Polyhedron 2009, 28, 511-520.

[41] H. Elias, E. Hilms and H. Paulus, Z. Naturforsch. Sect. B 1982, 37 , 1266-1273.
[42] J. Wang and Z. You, Acta Crystallographica Section E-Structure Reports Online 2007, 63, M1200-M1201.

[43] A. N. Shnulin, Y. T. Struchkov, K. S. Mamedov, A. A. Medzhidov and T. M. Kutovaya, J. Struct. Chem. 1977, 18, 799-805.

[44] R. Gebbink, M. Watanabe, R. C. Pratt and T. D. P. Stack, Chem Commun. 2003, 630-631.

[45] A. Altomare, M. Burla, M. Camalli, G. Cascarano, C. Giacovazzo, A Guagliardi, A. Moliterni, G. Polidori and R. Spagna, J. Appl. Cryst. 1999, 32, 115-119.

[46] G. M. Sheldrick, Acta Crystallogr., Sect. A: Found. Cryst. 2008, 64, $112-122$.

[47] L. J. Farrugia, J. Appl. Crystallogr. 1997, 32, 565.

Received: ((will be filled in by the editorial staff)) Published online: ((will be filled in by the editorial staff)) 
Neutral monochloride $\mathrm{Cu}^{\mathrm{II}}$ complexes with dialkylaminoethyl-functionalized $\beta$-ketiminato ligands have been synthesized and shown to control the radical polymerization of styrene under reverse ATRP conditions. A structural comparison between the dimethyl and diethylamino compounds reveals a delicate balance between mononuclear and dinuclear arrangements in the solid state.

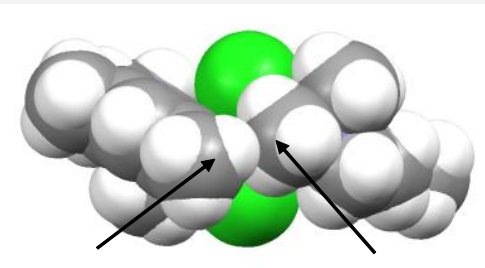

Stefano Gulli, Jean-Claude Daran,

Rinaldo Poli* ..... Page No. - Page No.

Synthesis and structure of 4-coordinate copper(II) complexes stabilized by $\beta$ ketiminato ligands and application in the reverse ATRP of styrene

Keywords: Copper / Functionalized $\beta$ ketimidato ligands / Controlled Radical Polymerization / ATRP / Polystyrene 
